\title{
Metaphysic Dimension in Labuhan Ceremony of Yogyakarta Palace
}

\author{
Sri Sudarsih ${ }^{*}$ \\ Department of History, Faculty of Humanities, University of Diponegoro, Kampus \\ Undip Tembalang, Semarang - 50275, Central Java, Indonesia
}

\begin{abstract}
The symbolic behavior in Javanese culture is reflected in labuhan ceremony which is done at certain moments by Yogyakarta Palace. This tradition is based on values and has a specific purpose. Labuhan ceremony has strong cultural roots associated with metaphysical meanings. The material object in this study is labuhan ceremony by Yogyakarta Palace, while the formalized object is metaphysics. This research is a qualitative research in philosophy. The method used is the method of analysis-synthesis with methodical interpretation. The existence of labuhan ceremony is regarded as the metaphysical type of communication between the world and the supernatural nature. Both have a reciprocal relationship so that labuhan ceremony is a form of communication to maintain harmony. Labuhan ceremony has a metaphysical meaning, which is a symbol of a harmonious relationship among human beings, supernatural nature, and God.
\end{abstract}

\section{Introduction}

Translating life philosophically can be done based on cultural patterns. One such pattern is the mythic culture. Even though all human lives cannot be separated from other patterns such as ontological and functional. Peursen stated that the entire level of human life in both primitive and modern life cannot be removed from the three patterns, so that the most important in human beings as cultural subjects. Peursen has mapped three cultural charts that always surround each culture, namely the mythic stage, the ontological stage, and the functional stage [1].

This mythic attitude is still felt in modern culture. These steps are not historically viewed solely, the one that appears after the other stage, but shows the stages contained in each culture. The question that arises later is how human positions itself on the development of culture. Symbolic behavior in Javanese culture, for example, is labuhan ceremony which is carried out at certain times by Yogyakarta Palace until now. This tradition has a purpose, value, way, and is done in a particular place.

Seeing these symbolic action patterns tends to have a more distant meaning instead of merely a visible act. If associated with the history of the establishment of Yogyakarta Palace, labuhan ceremony has a strong cultural roots associated with metaphysical meanings. Life within the Javanese culture that is always based on metaphysical values then labuhan

* Corresponding author: srisudarsih012005@yahoo.com 
ceremony has its own purpose. The fundamental issue in this research is the metaphysical basis in labuhan ceremony by Yogyakarta Palace.

Yogyakarta Palace was chosen because it has a specific value background. According to Mulder, when conducting research on Java, it could not be separated from the city of Yogyakarta. According to him, many things and information can be obtained from Yogyakarta. Yogyakarta is in every sense more truly Javanese than anywhere else. Yogyakarta City has a very long history. This city is one of the heirs of the Mataram Kingdom in the XVII century and is the Kingdom of the Sultanate (Vorstenland) which still exists today. The oldest monuments of civilization, such as Hinduism and Buddhism, are scattered in and around Yogyakarta. Yogyakarta is the point of acculturation of various cultural elements. As a Sultanate area, Yogyakarta was never colonized because before the Unitary State of Republic of Indonesia, Nagari Ngayogyakarta was already established. During the independence movement of Republic of Indonesia, Yogyakarta is the place where several were founded national social organizations that inspired youth movements such as Budi Utama, Muhammadiyah, and Perguruan Taman Siswa. During Indonesia's independence, Yogyakarta became the temporary capital to save the Republic of Indonesia. Because of these various roles, Yogyakarta has gained the status of a special area, known as the Special Region of Yogyakarta (Daerah Istimewa Yogyakarta) [2]. Currently Yogyakarta, which has a population of around 3.5 million, has hundreds of universities with hundreds of thousands of students from various parts of Indonesia. One of the oldest tertiary institutions is Gadjah Mada University with more than 60,000 students. Yogyakarta is known as the city of culture and city of students. Yogyakarta is also the second tourist destination after Bali. Many national figures, regional officials and great artists were born and emerged from this city.

\section{Methods}

\subsection{Research Stages}

- Exploration of literary sources. At this stage the researcher determines the location of the data source, namely libraries, study centers, or research centers.

- The stage of collecting library data is in the form of books and other literature related to the object of research, both formal objects and material objects.

- The data processing stage is carried out by carrying out an inventory, systematizing, and classifying data relating to labuhan ceremony and metaphysics.

- Data analysis stages. Data relating to labuhan ceremony and metaphysics that have been inventoried, systematized, and classified are then analyzed using the relevant method and methodical elements. 


\subsection{Data Analysis}

This research is a qualitative research in philosophy. The method used is the method of analysis-synthesis with methodical interpretation.

\section{Results and Discusion}

\subsection{Metaphysics Meaning}

Philosophy as a critical study of everything in the universe puts a metaphysics position as a crucial point of study, even Rene Descartes, the main character of Modern Western philosophy stated that the metaphysics are the roots of the tree of science. The tree is physics, while the brances are other brances of science [3].

Metaphysics is a branch of philosophy that deals with issues of existence. The term metaphysics means something behind physical objects [4]. Aristotle mentions several terms of meaning equivalent to metaphysics, such as the first philosophy, knowledge of causation and theology [5].

\subsection{Metaphysics Issues}

Until now there is no agreement on actual metaphysics issues because each philosopher departs from a different point of view. Nevertheless, we need to look at between Frederick Sontag and Anton Bakker, for example, there is indeed a tangent point. The two figures agreed that metaphysics examines 'being'. Researchers specifically use the theory of Bakker. Bakker explains that ontology or general metaphysics is a branch of philosophy that answers the issue and holds an overview of the existing structure or absolute reality for all types of reality [6].

Bakker in his book, Ontology or General Metaphysics (1992) explains the six fundamental problems that become ontological studies. First, the question of whether reality is many or one? Secondly, what is the question of whether reality has a transcendent homogal trait? Thirdly, the question of whether reality has a permanence or novelty? Fourth, the question of whether dimensional reality is physical or spiritual? Fifth, the question of whether the reality presence is worth or not? Sixth, the question of whether in reality is found the transcendental ontological norm that applies to all? Researchers used five issues to analyse labuhan ceremony of Yogyakarta Palace [6].

\subsection{Labuhan Ceremony}

Labuhan ceremony is one of the traditional ceremonies held regularly since Sri Sultan Hamengku Buwono I until now and still affects the life of Yogyakarta people. The community believes that by convening labuhan ceremony then the safety, tranquility, and welfare of the community and the country can be maintained. Humans are cultural creatures. Human culture is close to the symbols, as did the Javanese. The symbol is attributed to tradition and mystical [7]. The symbol for the Javanese has a metaphysical meaning, as well as labuhan ceremony means relating to the symbols.

Labuhan ceremony contains a sense of throwing something into the water (sea for example) or certain places according to the customs of palace. The general public, especially Yogyakarta residents still believe in the influence of mythic the king, palace, and the heritage of the palace. Therefore every time ceremony is held, citizens willingly jostle to acquire 
objects that have to do with the ceremony to seeking blessings. The king is thought to have supernatural charisma and strength. The body parts of the king are considered to possess strong strength, such as hair and nails [8].

In principle, the purpose of labuhan ceremony is for the personal safety of Sri Sultan, palace, and people. In the broad sense of this ceremony to achieve the safety and harmony of the universe, both nature in the sense of the world objective and nature in the metaphysical sense that can only be experienced and felt inward.

Labuhan ceremony, as explained by Sumarsih. Sumarsih accompanied by the equipment (uba rampe) containing certain meanings manifested in the form of symbols, including:

- Apem. This apem is equipped with sticky rice and kolak. These three foods for Javanese people symbolize apologies to God.

- Tumpeng adhem-adheman. This tumpeng dish is intended so that the atmosphere of the palace and its surroundings is always calm or adhem.

- Tukon pasar. Tukon pasar consists of a variety of fruits and snacks. This dish is intended so that the people (kawula) whose life is from a trading business can achieve success.

- $\quad$ Tumpeng Woran. This dish is intangible rice and severel kinds of side dishes, which symbolize that each individual can interact with other individuals such as fraternity relationships.

- Dhahar Kebuli. This food is the favorite of Sri Sultan Hamengku Buwono I.

- Dhahar Punar. This dish is a yellow rice (nasi kuning) for those who have gold deposits.

- Tumpeng urubing damar. This tumpeng is plugged in a ligand on it, the ends are given cotton so that the form of lamps. This tumpeng is a symbol so that a king can give bright rays to his people.

- Tumpeng Ropoh. Tumpeng and side dishes are put into takir (like a bowl formed from banana leaves). This tumpeng is a symbol of hope so that every individual can interact with other individuals such as brotherly relationship.

- Tumpeng Yuswa. The tumpeng consists of a large tumpeng which is surrounded by small tumpeng that are entirely adjusted to the age of Sri Sultan which is calculated according to the date of Java. This tumpeng symbolizes the hope that Sri Sultan is long life.

- The golden yellow umbrella symbolizes the position of a king.

- Other equipment is dhahar rasulan, which is equipped with a chicken ingkung. Chickens that are made ingkung are those have black feathers. The color black is considered to mean sincerity a king [9].

Based on the above explanation, it can be concluded that labuhan ceremony which is held annually by Yogyakarta Palace is a symbol of harmonious relationship among human beings, supernatural nature, and God.

\subsection{Reality in Labuhan Ceremony}

\subsubsection{Quantity-Reality}

The first fundamental problem in ontology is the question of whether reality is many or one?

The reality according to the Javanese as stated by Bakker is to be in unity with The Absolute. This unity is still temporary in the world (miyos), but permanent in the afterlife, namely Pamoring Kawula lan Gusti [6]. 
Javanese people realize that humans are creations of God and are part of nature. With regard to this, Mulder stated that humans and nature in the view of Javanese Philosophy have a very close relationship because cosmologically life in the world is part of the unity. In that unity, all the symptoms have a place and are in complementary relationships and coordinated with one another. The unity of existence has a culminating point at the center which encompasses everything in the Most One [2].

Based on the understanding, human beings have an obligation to align with nature, both the sensory nature and the supernatural nature. The ceremony is a form of human expression in the harmonising with nature. Labuhan ceremony is a form of recognition of the reality that can be senses and creatures that cannot be senses. The ceremony is a testament to the fact that between the real and supernatural nature is a reality that can be mutually inseparable. When there is a disaster for example, the solution is metaphysical. Therefore, each year is held by labuhan as a form of mutual relationship.

For Javanese people harmonious relations with nature should be kept in harmony. Nature and humans are one regular entity. Based on that explanation, it can be concluded that labuhan ceremony as a symbol of Javanese Philosophy is tendencies monistic. All came from God as the creator of nature and finally returned to God.

\subsubsection{Dynamics of Reality}

The fundamental question here is about whether the reality has a permanence or novelty? Concerning this principle we need to seek in real life forms in existence and supernatural. As in labuhan ceremony, we can distinguish two different worlds, but the two worlds are clearly intertwined. An outward welfare is influenced by the spirit. In this case it is obvious that the relationship is permanent but the form is always dynamic. There is a mutually filled alignment relationship. The relationship itself comes down to the king.The king is seen as a manifestation of God who is in the world or manifests in his power. God is the most perfect and eternal immortal. Unlike people who are constantly changing like wheels that spin and evolve but don't lose their identity.

\subsubsection{Physical and Spiritual}

The fundamental question here is about whether it is a physical or spiritual dimensional reality? If applied to labuhan ceremony then between matter and spiritual is two things that can not be separated, but there is a tendency that the transcendence of the spirit is above the material. The reality of labuhan is a metaphysical event symbolized by equipment. The physical world draws itself into the spiritual world. Uba rampe in the ceremony as a means to the dialogue level of the spirit. Mantera as well as prayers that are spoken by the leaders of the ceremony serve as intermediates of two worlds so that both the physical and spiritual world have causal relationships and metaphysical relationships.

\subsubsection{Meaning and value of reality}

The fundamental issue here is about whether the presence of reality is worth or not? According to Javanese Philosophy, life is experienced in taste. Reality has meaning and value [6]. Reality itself can only be caught in a sense of the level. Reason is only considered able 
to capture the reality that can be seen with the senses. In order to attain the awareness of taste is described in Dewaruci, a teaching journey of a disciple who wants to reveal a secret 'Being'. Bimo through certain stages finally come to the most deep understanding of taste. It is actually a personal practice. Sense means feeling in all dimensions [10].

Similarly, in labuhan ceremony which has a metaphysical meaning and can only be understood with taste. A sense of union with the Divine. Taste is interpreted as eling, remembering the origin of humans.

\subsubsection{Reality objectives}

The fundamental question here of whether in reality is found the transcendental ontological norm that applies to all? Harmony, conformity, and balance are signs of goodness and righteousness. The classification of natural directional toward harmony and seeks to unite with Sang Hyang Widdhi. Forms of conflict (such as sin and disaster) must be cleaned to achieve harmony, in an increasingly complete and unified level [6].

If this is applied to the ceremony, it can be concluded that the ceremony aims to align itself with supernatural nature, to avoid disaster. It means labuhan as a human effort with the cosmos and culminates in the Almighty, that is to achieve life perfection so that in the end people can unite with God (Pamoring Kawula lan Gusti). The soul of sejatining manungsa means a vertical relationship, namely the relationship between humans and Creator.

This proves that in Javanese Philosophy there are deficiencies, therefore labuhan ceremony is an effort to clean oneself by throwing something into the water (sea) or to certain places such as mountains, so that harmony occurs.

\section{Conclusion}

The existence of labuhan is seen as a communication between this world and the supernatural world. Labuhan ceremony as a symbol of harmony relationship. In conjunction with both of these worlds, the king's position is seen as the most central thing because the king with his power is able to restore balance, in case of dis-harmonization of his second relationship, which can sometimes bring disaster. The term ngalab berkah in labuhan that is done by the public to acquire the objects that are crushed is an attempt to gain the power of the king so that it can bring prosperity. Dynamic relationships can always be maintained if labuhan is carried out continuously.

Labuhan as a symbol of Javanese Philosophy in the monistic tendencies. All came from God as the creator of nature and finally returned to God. Labuhan ceremony as an effort to align themselves to nature, as evidence that humans with nature is a whole, the unity of Microcosm (jagad cilik) and Macrocosm (jagad gedhe).

Labuhan is a form of recognition that there is a supernatural nature, in addition to this nature (physical nature). The outward welfare was influenced by the physical. Reality, its relationship is permanent, but the shape is always dynamic. There is a mutually filled alignment relationship. The relationship comes down to the king, because the king as a manifestation of God or reflected especially in the king's dominion.

God is most perfect and immortal eternal, different from human beings. Reality is physical and spiritual, they are inseparable and influence each other, but there is a tendency that the transcendence of the spirit is above the material. The reality is tan kena kinaya apa, tan iki iku, but life experienced in taste. While the purpose of reality in labuhan ceremony is universal harmony, containing human meaning with the cosmos and culminating in the Almighty, namely achieving the perfection of life Pamoring Kawula lan Gusti. 


\section{References}

1. C.A. Van Peursen, Strategi Kebudayaan, Yogyakarta: Kanisius, 17-19 (1988).

2. N. Mulder, Kebatinan dan Hidup Sehari-hari Orang Jawa: Kelangsungan dan Perubahan Kultural, Jakarta: Gramedia, xxi, 17-18 (1985).

3. W. E. Kennick, M. Lazerowitz, Metaphysics, New Jersey: Prentice-Hall, Inc, Englewood Cliffts (1966).

4. L. Bagus, Kamus Filsafat, Jakarta: Gramedia Pustaka Utama, 623 (1996).

5. A. R. White, Methods of Metaphysics, New York: Croom Helm Ltd., 31 (1987).

6. A. Bakker, Ontologi: Metafisika Umum, Filsafat Pengada dan Dasar-Dasar Kenyataan, Yogyakarta: Kanisius, 9-10, 25-193 (1992).

7. B. H. Satoto, Simbolisme Dalam Budaya Jawa, Yogyakarta: Hanindita, 9 (2003).

8. Supanto, Masyarakat Pedesaan Yogyakarta dan Berbagai Bentuk Pernyataan Kebudayaan, Yogyakarta: Asita, 23, 24 (1983).

9. S. Sumarsih, Suhatno, R. A. Maharkesti, Upacara Tradisional Labuhan Kraton Yogyakarta. Yogyakarta: Departemen Pendidikan dan Kebudayaan Direktorat Jenderal Kebudayaan Direktorak Sejarah dan Nilai Tradisional Proyek Inventarisasi dan Pembinaan Nilai-Nilai Budaya, 115-118 (1989).

10. F. M. Susena, Etika Jawa: Sebuah Analisa Filosofis Tentang Kebijaksanaan Hidup Jawa, Yogyakarta: Kanisius, 130 (1996). 